\title{
THE IMPACT OF AGRICULTURAL MANAGEMENT PRACTICES ON NUTRIENT LOSSES TO WATER: DATA ON THE EFFECTS OF SOIL DRAINAGE CHARACTERISTICS
}

\author{
*Kurz, Isabelle ${ }^{1}$, Tunney, H. ${ }^{1}$, Coxon, C.E. ${ }^{2}$. \\ ${ }^{1}$ Teagasc, Johnstown Castle, Wexford, ${ }^{2}$ Department of Geology, Trinity College, Dublin.
}

\begin{abstract}
Against the background of increasing nutrient concentrations in Irish water bodies, this study set out to gain information on the potential of agricultural grassland to lose nutrients to water. Overland flow, flow from artificial subsurface drains and stream flow were gauged and sampled during heavy rainfall events. Dissolved reactive phosphorus (DRP), potassium (K), total ammonia (TA), and total oxidised nitrogen (TON) were measured in water samples. When the nutrient concentrations in water were examined in relation to the grassland management practices of the study catchments it emerged that soil P levels, the application of organic and inorganic fertilisers before heavy rainfall and the presence of grazing animals could all influence nutrient concentrations in surface and subsurface drainage water. Overall, the drainage characteristics of soil were found to have a considerable influence on the potential of land to lose nutrients to water.
\end{abstract}

Keywords: management practices, nutrient losses, site characteristics.

\section{INTRODUCTION}

The over-fertilisation, or eutrophication, of water bodies, and its negative impacts on aquatic ecosystems and on water as a resource for domestic, industrial, agricultural and recreational usage (Vollenweider, 1971) have been a serious concern for a number of years in many countries. In Ireland, about $30 \%$ of river channel surveyed by the Environmental Protection Agency (EPA), and a number of estuaries and lakes, showed signs of eutrophication in the late 1990s (McGarrigle et al., 2002). Diffuse loss of nitrogen (N) and phosphorus (P) from agriculture was one of the reasons named for the elevated nutrient concentrations in some water bodies. Agricultural management practices, site characteristics, such as soil hydrology, for example, and the weather are the most important factors influencing nutrient losses from agricultural grassland (Gardiner, 1986; Pote et al., 1999). To define effective strategies for reducing diffuse nutrient losses from agricultural grassland, nutrient source areas must be identified and described, and potential losses quantified. The focus of this study was on investigating the nutrient loss potential of pasture areas. All study sites were located within the boundaries of Johnstown Castle Estate, Wexford.

\section{METHODS}

\section{Description of the Study Sites and Water Monitoring Programme}

The potential of pasture areas to lose N, P and K via surface and/or shallow subsurface flow pathways was assessed at different scales. Edge-of-field measurements of the quality and quantity of overland flow served to estimate nutrient losses from pasture areas on poorly drained soils (Warren, Cowlands) from $24^{\text {th }}$ November 1996 to $31^{\text {st }}$ March 1998. Nutrient losses in shallow subsurface flow were assessed by monitoring the discharge from an artificial subsurface drainage network (Beef Unit) from $4^{\text {th }}$ November 1997 to $31^{\text {st }}$ March 1998. A small stream (surface and shallow subsurface water catchment area of about 100 ha) was monitored from $24^{\text {th }}$ November 1996 to $31^{\text {st }}$ May 1997 to gain information on nutrient exports from large proportions of the beef operation (Beef Unit) and the dairy enterprise (Dairy Farm) at Johnstown Castle Estate. 
Both overland flow monitoring sites (Warren, Cowlands) had been set up on gley soils. The Warren covered an area of 1.54 ha and the Cowlands an area of 0.46 ha. A combination of open trenches and berms was used to hydrologically isolate the surface of these sites from surrounding land. The overland flow arising on the study areas was collected, measured and sampled automatically.

Shallow subsurface flow and overland flow from land of the beef enterprise and the dairy operation at Johnstown Castle flow into a small stream, which runs underground in large concrete pipes for most of its course. The two areas contributing to stream flow were named 'Beef Unit' (approximately 24 ha) and 'Dairy Farm' (approximately 70 ha), respectively. The Beef Unit is situated upstream of the Dairy Farm. The soils at the Beef Unit and the Dairy Farm range from poorly and imperfectly drained gleys to well drained brown earths. The percentage of soils of impeded (poor and imperfect) drainage amounts to $79 \%$ of the Beef Unit catchment and to $28 \%$ at the Dairy Farm sub-catchment. In both areas, artificial subsurface drainage systems were installed in the 1970s to improve drainage of poorly and imperfectly drained soils. The artificial subsurface drainage system of the Beef Unit drains about 24 ha of the permanent grassland to a point just upstream of the farm buildings of the beef enterprise. This point (MB) was used to monitor the discharge from the subsurface drainage network. Some of the water in the subsurface drains is groundwater because a spring contributes to the flow in the artificial subsurface drainage network. The end of the drainage network forms the starting point of the small stream running, mainly underground in concrete pipes, from the Beef Unit down to and through the Dairy Farm. Just downstream of the end of the subsurface drainage network (MB) overland flow from the land of the Beef Unit also flows into the stream via an open access hole.

From the Beef Unit, the stream runs underground for a distance of $0.5 \mathrm{~km}$ to the upstream monitoring station of the Dairy Farm sub-catchment (M1). As only some overland flow from the road can flow into the stream along this stretch, the stream water at the upstream monitoring station of the Dairy Farm sub-catchment (M1) is, at high flow, largely representative of the stream water as it leaves the Beef Unit. The stretch of stream between the upstream (M1) and the downstream (M2) monitoring stations at the Dairy Farm sub-catchment is about $1.1 \mathrm{~km}$ long. Large sections of the stream as it runs through the Dairy Farm are underground but overland flow does gain access to the stream along two stretches.

Water depth and velocity meters integrated into automatic samplers were used for recording flow at the discharge point of the artificial subsurface drainage network at the Beef Unit (MB), at the upstream (M1) and downstream (M2) monitoring stations of the Dairy Farm sub-catchment. There was year round flow in the stream from the Beef Unit (MB) to the end of the Dairy Farm (M2). At all three sites, flow-proportional sampling programmes during high flow conditions were triggered by a water level rise.

\section{Management of the Study Sites}

The overland flow sites had been managed as a high soil fertility (Cowlands) and a low soil fertility (Warren 1) grassland for over a decade before the start of this study. During that time, the site at the Cowlands had been used as part of a rotational grazing system between the end of March and the end of October, whereas the site at the Warren had often been cut for hay. Grazing animals (opportunity grazing) were re-introduced to the Warren for the grazing season following the start of the monitoring programme. The soil $\mathrm{P}$ level at the Cowlands was high $\left(17 \mathrm{mg} \mathrm{P}^{-1}\right.$ Morgan's on average with a range of 14 to $21 \mathrm{mg} \mathrm{P}^{-1}$ ) and the soil $\mathrm{P}$ level at the Warren was low (4 $\mathrm{mg} \mathrm{P}^{-1}$ Morgan's with a range of 3 to $4 \mathrm{mg} \mathrm{P}^{-1}$ ). Fertiliser applications were carried out as required by the two grazing systems. The Warren received small $\mathrm{N}\left(27 \mathrm{~kg} \mathrm{~N} \mathrm{ha}^{-1}\right)$ and $\mathrm{K}\left(31 \mathrm{~kg} \mathrm{~K} \mathrm{ha}^{-1}\right)$ dressings each July and the fertiliser applications at the Cowlands are detailed in Table 1. 
The soil $\mathrm{P}$ levels in the Beef Unit ranged from 4 to $12 \mathrm{mg} \mathrm{P}^{-1}$ Morgan's and the area weighted average was $8 \mathrm{mg} \mathrm{P} \mathrm{l}^{-1}$. The soil P levels at the Dairy Farm also averaged (area weighted) at $8 \mathrm{mg} \mathrm{P}$

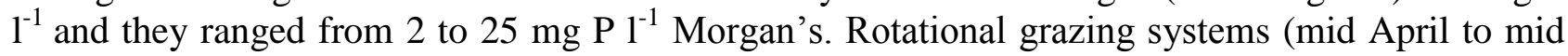
October) at an average annual stocking rate of about 2 livestock units per ha were operated on the land of the Beef Unit and the Dairy Farm. Dates and types of fertiliser applied to the Beef Unit catchment and the Dairy Farm sub-catchment are detailed in Table 1. (Note that fertilisation rates varied between fields. They are therefore not listed.)

Table 1: Fertiliser applications at the Cowlands, the Beef Unit and the Dairy Farm.

\begin{tabular}{|c|c|}
\hline Site & Fertiliser use \\
\hline \multicolumn{2}{|l|}{ COWLANDS } \\
\hline $\begin{array}{l}\text { Jan-Dec } \\
1997\end{array}$ & $\begin{array}{l}\text { Phosphorus: } 30 \mathrm{~kg} \mathrm{P} \mathrm{ha}^{-1} \text { on } 20^{\text {th }} \text { March as superphosphate. } \\
\text { Potassium: } 31 \mathrm{~kg} \mathrm{~K} \mathrm{ha}^{-1} \text { on } 20^{\text {th }} \text { March as muriate of potash. } \\
\text { Nitrogen: } 57 \mathrm{~kg} \mathrm{~N} \mathrm{ha}^{-1} \text { on } 19^{\text {th }} \text { March as urea, } 67 \mathrm{~kg} \mathrm{~N} \mathrm{ha}^{-1} \text { on } 8^{\text {th }} \text { May as CAN } \\
\text { and } 67 \mathrm{~kg} \mathrm{~N} \mathrm{ha}^{-1} \text { as CAN in July } 1997 \text {. }\end{array}$ \\
\hline Jan-March 1998 & Nitrogen: $57 \mathrm{~kg} \mathrm{~N} \mathrm{ha}^{-1}$ on $5^{\text {th }}$ March as urea. \\
\hline \multicolumn{2}{|l|}{ BEEF UNIT } \\
\hline $\begin{array}{l}\text { Jan-May } 1997 \\
\end{array}$ & $\begin{array}{l}\text { Phosphorus: February } 1997 . \\
\text { Potassium: February } 1997 . \\
\text { Nitrogen: March, April and May } 1997 .\end{array}$ \\
\hline Jan-March 1998 & $\begin{array}{l}\text { Nitrogen: } 4^{\text {th }} \text { March } 1998 . \\
\text { Slurry: } 20^{\text {th }} \text { and } 27^{\text {th }} \text { February } 1998 .\end{array}$ \\
\hline \multicolumn{2}{|l|}{$\overline{\text { DAIRY FARM }}$} \\
\hline Jan-May 1997 & $\begin{array}{l}\text { Phosphorus: Beginning of March and beginning of May } 1997 . \\
\text { Potassium: Beginning of March and beginning of May } 1997 . \\
\text { Nitrogen: } 25^{\text {th }} \text { to } 27^{\text {th }} \text { February, } 31^{\text {st }} \text { March to } 4^{\text {th }} \text { April and } 5^{\text {th }} \text { to } 7^{\text {th }} \text { May } 1997 . \\
\text { Slurry: } 21^{\text {st }} \text { to } 23^{\text {rd }} \text { January } 1997 \text {. }\end{array}$ \\
\hline
\end{tabular}

\section{Measures of Water Quality}

Phosphorus was measured in filtered (filter size of $0.45 \mu \mathrm{m}$ ) water samples by the automated ascorbic acid reduction method (Anon, 1995). According to Anon (1995), this fraction of $\mathrm{P}$ is named dissolved reactive $\mathrm{P}$ (DRP) even though the measurement is known to include $\mathrm{P}$ bound to colloids smaller than $0.45 \mu \mathrm{m}$ (Anon, 1995). The total ammonia (TA) measurement was based on the reaction of ammonia with saliclyate and dichloroisocyanurate in alkaline solution. The automated hydrazine reduction method was used for total oxidised nitrogen (TON) determination (Anon, 1995). Potassium (K) levels were measured by flame atomic absorption spectrometry. All sampling bottles were acid washed after use.

During storm flow producing rainfall events, water samples were collected from the automatic samplers at the study sites every morning and analysed for DRP, TON and TA within 24 hours (longer during weekends) of sampling. When the laboratories were closed or staff were not available to operate the automatic analyser, DRP/TON/TA analysis was not carried out.._This affected some of the samples taken in July/August 1997 and in December/January 1997/98. For these periods, DRP concentrations were estimated from total dissolved P data (not presented here).

\section{RESULTS AND DISCUSSION}

\section{Overland flow}

On an annual basis, $62 \%$ of the rainfall became overland flow at the Warren (low soil P site), whereas the flow from the Cowlands (high soil $\mathrm{P}$ site) amounted to $36 \%$ of rainfall. The flow- 
weighted average DRP concentrations for the overland flow events monitored during the 16 months period ranged from $0.013 \mathrm{mg} \mathrm{Pl}^{-1}$ to $1.050 \mathrm{mg} \mathrm{P} \mathrm{l}^{-1}$ at the Warren, and from $0.122 \mathrm{mg} \mathrm{P} \mathrm{l}^{-1}$ to 5.102 mg P $1^{-1}$ at the Cowlands. These figures and the overall maximum and minimum values listed in Table 2 illustrate that the DRP levels in overland flow varied greatly between overland flow events and between sites. During all but the last recorded overland flow event, the DRP concentrations were greater in overland flow from the Cowlands than in overland flow from the Warren. Pote et al. (1999) describe positive relationships between soil P and P in overland flow. It is therefore likely that the higher soil $\mathrm{P}$ status, or a related factor such as the higher $\mathrm{P}$ concentrations in herbage or manure, led to the consistently greater DRP values measured at the Cowlands than at the Warren.

Table 2: Averages and ranges of nutrient concentrations in water samples from the study sites.

\begin{tabular}{|c|c|c|c|c|c|}
\hline $\mathrm{Nu}$ & W & $\begin{array}{c}\text { Cowlands } \\
\text { (overland } \\
\text { flow) }\end{array}$ & $\begin{array}{c}\text { Beef Unit } \\
\text { (subsurface } \\
\text { drainage, MB) }\end{array}$ & $\begin{array}{r}\text { U/s Dairy } \\
\text { (stream, }\end{array}$ & $\begin{array}{c}\text { D/s Dairy } \\
\text { Farm } \\
\text { (stream, M2) }\end{array}$ \\
\hline $\begin{array}{ll}\text { DRP } & \text { Average } \\
\left(\mathrm{mg} \mathrm{Pl}^{-1}\right) & \text { Range }\end{array}$ & $\begin{array}{r}0.07 \\
<0.005 \mathrm{tc}\end{array}$ & $\begin{array}{r}0.8 \\
0.095 \mathrm{t}\end{array}$ & 0123 & 0.201 & $\begin{array}{r}0 . \\
0.005\end{array}$ \\
\hline $\begin{array}{ll}\mathrm{K} & \text { Average } \\
\left(\mathrm{mgl}^{-1}\right) & \text { Range }\end{array}$ & $\begin{array}{c}9.7 \\
<0.1 \text { to }>80\end{array}$ & $\begin{array}{c}16.1 \\
0.5 \text { to }>\varepsilon\end{array}$ & $\begin{array}{r}6 \\
1.7 \mathrm{t}\end{array}$ & 8.9 & $\begin{array}{r}6 \\
<0.1 \mathrm{t}\end{array}$ \\
\hline $\begin{array}{ll}\text { TA } & \text { Average } \\
\left(\mathrm{mg} \mathrm{Nl}^{-1}\right) \text { Range }\end{array}$ & $\begin{array}{r}0 . \\
<0.1\end{array}$ & $\begin{array}{r}2.2 \\
<0.1 \mathrm{t}\end{array}$ & $\begin{array}{r}0 . \\
<0.1 \mathrm{t}\end{array}$ & $\begin{array}{c}0.28 \\
<0.1 \text { to } 3.90\end{array}$ & $\begin{array}{c}0.14 \\
<0.1 \text { to } 2.40\end{array}$ \\
\hline $\begin{array}{ll}\text { TON Average } \\
\left(\mathrm{mg} \mathrm{Nl}^{-1}\right) \text { Range }\end{array}$ & $\begin{array}{c}<0.3 \\
<0.3 \text { to } 9.1\end{array}$ & $\begin{array}{c}1.6 \\
<0.3 \text { to } 49.3 \\
\end{array}$ & $\begin{array}{c}3.4 \\
<0.3 \text { to } 6.0\end{array}$ & $\begin{array}{c}5.3 \\
<0.3 \text { to } 9.6\end{array}$ & $\begin{array}{c}5.3 \\
<0.3 \text { to } 8.7 \\
\end{array}$ \\
\hline
\end{tabular}

$*$ As the total amount of overland flow from these sites was measured, flow-weighted averages are listed.

As concentrations of all the nutrients considered were very variable during and between overland flow events (Table 2), it was difficult to find clear evidence of the impact of the management practices listed in Table 1 on nutrient concentrations in overland flow from the study sites. Nonetheless, the data from the Cowlands (high fertility site) showed up some trends.

The DRP levels at the Cowlands were generally high. The minimum DRP concentrations and very low K levels were measured at the end of March 1998. The K levels were high in the first half of May 1997 but the main DRP and K peaks occurred during overland flow events at the beginning and towards the end of August 1997. These peaks may be attributable to the presence of grazing animals during and/or shortly before the occurrence of overland flow. High $\mathrm{P}$ concentrations in water have been identified as a consequence of the presence of grazing animals and their faeces (Heathwaite, 1993), and elevated $\mathrm{K}$ concentrations in overland flow after grazing have been observed (McColl, 1979). High P concentrations in overland flow after P fertiliser applications were measured in other studies (Nash et al., 2000). The overland flow event following P fertilisation at the Cowlands (fertilisation $20^{\text {th }}$ March 1997), however, was not characterised by exceptionally high $\mathrm{P}$ levels. It is likely that the effect of $\mathrm{P}$ fertilisation was not detectable because the overland flow event started as much as 44 days after the fertiliser application.

The TON levels were normally low but some of the concentrations measured $9 / 10^{\text {th }}$ May and $18 / 19^{\text {th }}$ May were very high. The maximum TON level during these events amounted to $49.3 \mathrm{mg} \mathrm{N}$ $1^{-1}$. Two smaller peaks with maximum values of 8.3 and $9.9 \mathrm{mg} \mathrm{Nl}^{-1}$ occurred on $5 / 6^{\text {th }}$ June and $20^{\text {th }}$ August. The TA concentrations were commonly below $5 \mathrm{mg} \mathrm{Nl}^{-1}$. Higher concentrations occurred during several events though. Exceptionally high TA levels were measured $9 / 10^{\text {th }}$ May, $18 / 19^{\text {th }}$ May, $20^{\text {th }}$ August 1997 and $6^{\text {th }}$ to $10^{\text {th }}$ March 1998. The high TA and TON levels in overland flow on $9 / 10^{\text {th }}$ May and $18 / 19^{\text {th }}$ May 1997 are likely to have been due to calcium ammonium nitrate (CAN) applications prior to the occurrence of overland flow. Also, urea fertilisation preceded the 
excessively high TA levels in overland at the beginning of March 1998. These responses to N fertilisation are much in line with findings of other studies (Baker and Laflen, 1982). It is furthermore possible that the urea application of $5^{\text {th }}$ March 1998 effected a lowering of $\mathrm{P}$ concentrations in the overland flow event which occurred $24^{\text {th }}$ March 1998 to $30^{\text {th }}$ March 1998. This event started 19 days after urea fertilisation. It was characterised by low P levels in overland flow from the Cowlands both in absolute (lowest maximum $\mathrm{P}$ concentrations for the monitoring period at that site) terms and when compared to the P concentrations measured at the site at the Warren (see above). The urea application at the Cowlands may have led to a growth response, which depleted the available soil P pool near the soil surface. This is a likely scenario as half of the root mass of high fertility pasture is known to occupy the top $5 \mathrm{~cm}$ of soil (Gisi and Oertli, 1981). The theory is further backed by the fact that the potassium concentrations in samples from the Cowlands for this event were also depressed in relative and absolute terms. In his study of overland flow from sheep pasture, McColl (1979) also considers plant uptake responsible for low nutrient levels in overland flow in springtime.

\section{Artificial Subsurface Drainage Water}

As with the overland flow data, there was considerable variation in the levels of all water quality parameters in drainage water during and between high flow events (Table 2). There was a general trend of the $\mathrm{P}$ and $\mathrm{K}$ concentrations during high flow to decrease as the winter (wet season) went on. This trend was broken during the high flow event starting $26^{\text {th }}$ February 1998 . The maximum concentrations measured during that event were nearly as high as those measured at the beginning of November 1997. The high $\mathrm{P}$ and $\mathrm{K}$ levels monitored in subsurface drainage during late February/early March can probably be linked to the slurry application to some of the fields of the Beef Unit in late February (Table 1). Strong positive responses of $\mathrm{P}$ concentrations in subsurface drainage water to manure applications have been reported (Stamm et al., 1998).

TON concentrations above $4.0 \mathrm{mg} \mathrm{Nl}^{-1}$ were much more common in November to January than in February and March. The TA concentrations were below $1 \mathrm{mg} \mathrm{Nl}^{-1}$ for all high flow events except for the one at the beginning of the monitoring period and the one that started $26^{\text {th }}$ February 1998. During this high flow event, a maximum TA concentration of $18.8 \mathrm{mg} \mathrm{Nl}^{-1}$ was measured on $6^{\text {th }}$ March 1998. These high TA concentrations in subsurface drainage water occurred two days after fertilisation with urea. Urea was applied to the catchment of the artificial subsurface drains monitored on $4^{\text {th }}$ March 1998. Fertilisation occurred on the falling limb of the first twin peak of a high flow event. The subsequent rainfall on $5^{\text {th }}$ and $6^{\text {th }}$ March 1998 gave rise to drain flow characterised by high TA concentrations. Elevated TA levels in subsurface flow and in discharge from artificial subsurface drains after the application of ammonia containing fertiliser were also measured by Heathwaite (1993) and Gentry et al. (2000), respectively.

How representative the results presented here are of artificial subsurface drainage water from Irish grassland is unknown. The subsurface drainage system reported on here was more than 20 years old and very little maintenance work had been carried out on it. Also, the spring contribution to drain flow led to a dilution of the shallow subsurface drainage water monitored. Evidence of sagging ground above the main drain in the field upstream of the measuring station (MB), on the other hand, suggested the occurrence of bypass flow, and thus a greater risk of P loss, along the soil-backfill interface.

\section{Stream Water}

Again, the nutrient concentrations in stream water varied considerably during and between high flow events (Table 2, Figures 1 and 2). The TON levels upstream (M1) and downstream (M2) of the Dairy Farm were comparable. In general, the DRP, K and TA concentrations were higher at the upstream (M1) than the downstream (M2) monitoring station. Thus, at high flow, the Beef Unit 
catchment (which mainly determines water quality at M1) had the impact of raising nutrient levels in stream water whereas the Dairy Farm sub-catchment did not.

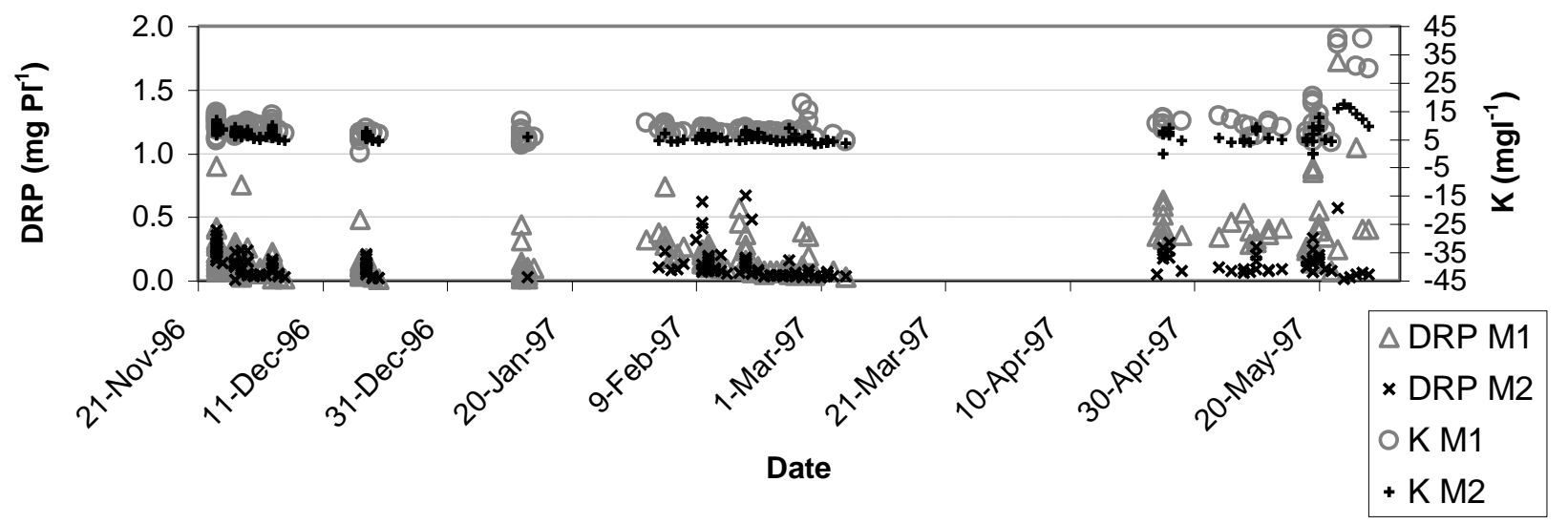

Figure 1: DRP and K concentrations in stream water at the upstream (M1) and downstream (M2) monitoring stations.

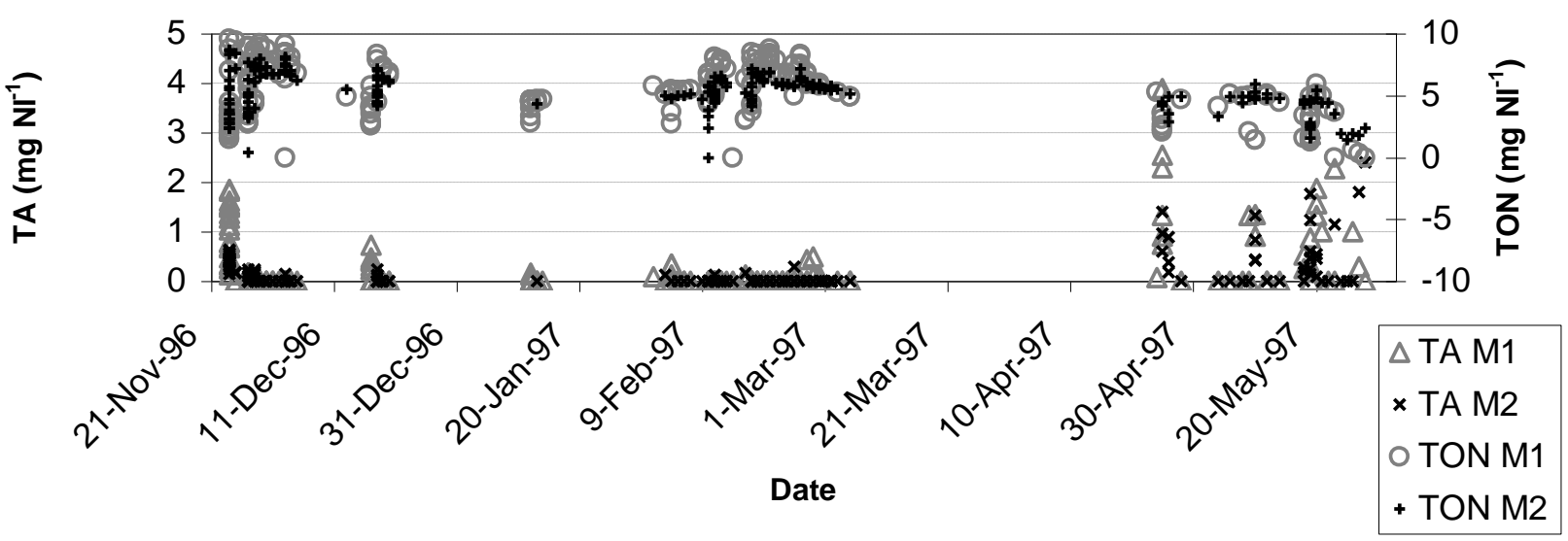

Figure 2: TA and TON concentrations in stream water at the upstream (M1) and downstream (M2) monitoring stations.

Figures 1 and 2 show the nutrient concentrations during high flow conditions at the two stream sites (M1, M2). Despite the fact that high flow occurred only just over a week after the January 1997 slurry application at the Dairy Farm (Table 1), there was no detectable influence of slurry spreading on the nutrient concentrations in stream water (Figures 1 and 2). Moreover, neither N applications in February and March nor N, P, K fertilisation in the Dairy Farm sub-catchment during May led to elevated levels of any of these nutrients in stream water.

An effect of fertilisation at the Beef Unit on water quality may, however, be detectable. The exact date of the P and K application to the land of the Beef Unit in February 1997 was not recorded. However, on $26^{\text {th }} / 27^{\text {th }}$ February there was a distinct DRP peak during the receding limb of the hydrograph. In the same samples $\mathrm{K}$ levels were clearly elevated (Figure 1). Furthermore, two obvious TA peaks $\left(25^{\text {th }}\right.$ April and $19^{\text {th }}$ May) (Figure 2) at the upstream monitoring station (M1) are likely to have resulted from $\mathrm{N}$ fertilisation at the Beef Unit in April and May (Table 1).

There was a marked overall increase in DRP, and to a lesser degree $\mathrm{K}$, concentrations at the upstream (M1) site at high flow after $24^{\text {th }}$ April 1997. The grazing season at both the Beef Unit 
catchment and the Dairy Farm sub-catchment commenced in mid April. It is therefore likely that elevated DRP and K levels downstream of the Beef Unit catchment after this date were evidence of the impact of the presence of grazing animals on stream water quality. No such effect was detectable as a result of grazing at the Dairy Farm sub-catchment.

The reactions of the stream chemistry to management practices at the Beef Unit are consistent with the connections between management operations and overland flow and artificial subsurface drain flow quality described above. Site characteristics and timing in relation to rainfall must have been responsible for the fact that management practices at the Beef Unit but not the Dairy Farm affected the storm flow nutrient levels in stream water. According to the evidence found in stream water, $\mathrm{P}$ and $\mathrm{K}$ application and some of the $\mathrm{N}$ fertilisation at the Beef Unit was carried out during or near wet periods. The same is true for slurry and some fertiliser applications at the Dairy Farm, however, and grazing animals were present in both areas during high flow conditions after mid April. Hence overland and shallow subsurface flow producing areas, and fast hydrological connections between the land and the stream must have been more prevalent at the Beef Unit catchment than the Dairy Farm sub-catchment. The greater proportion of poorly and imperfectly drained soils at the Beef Unit than the Dairy Farm lends support to this interpretation. Wet soils are likely to produce overland flow (Cooke and Dons, 1988), which is known to be an efficient mechanism of delivering nutrients to water bodies (McColl, 1979). Networks of artificial subsurface drains were installed to improve drainage of wet soils and, in some situations, artificial subsurface drains are thought to foster the development of preferential flow pathways (Dils and Heathwaite, 1996). Artificial subsurface rainage may thus have limited success in reducing the $\mathrm{P}$ losses from some wet areas (Hawkins and Scholefield, 1996). The nutrient loss potential of wet but artificially drained soils is likely to be greater than that of naturally well drained soils.

\section{CONCLUSIONS}

Poorly drained sites characterised by elevated soil P levels have a large potential to lose DRP to water bodies in overland flow. Twofold differences in overland flow between sites show that even within the poorly drained class there are still substantial differences in DRP export potential due to soil hydrology. The more than four times higher soil $\mathrm{P}$ level of high rather than low fertility grassland was reflected in a more than 11 times greater flow-weighted average DRP concentration of overland flow from the high rather than the low soil $\mathrm{P}$ site. The strong effect of a growth response, triggered by urea application, on DRP concentrations in overland flow may point towards a way of minimising DRP loss from wet, high fertility grassland in spring.

Effects of agricultural management practices on water quality were picked up in overland flow, artificial subsurface drain flow and stream water. At sites other than the Dairy Farm, nutrient levels in water were elevated when these elements were applied to land as organic or inorganic fertiliser just prior to heavy rainfall. The strong response of the subsurface water quality to slurry application at the Beef Unit in combination with a lack of a response of stream water quality to slurry spreading at the Dairy Farm was interesting. Generally, the same management practices carried out under similar conditions at the Beef Unit and at the Dairy Farm differed considerably in their impact on stream water quality. This suggests that rapid active hydrological connections between the stream and the land were of great importance at the Beef Unit but of minor significance at the Dairy Farm.

Overall, the drainage characteristics of soils were found to influence the potential of sites to lose nutrients to water considerably. The interactions between site hydrology, management practices, and the influence of management practices on each other, are best dealt with by detailed sitespecific nutrient management planning. 


\section{REFERENCES}

Anon. 1995. Standard methods for the examination of water and wastewater, $19^{\text {th }}$ edition. American Public Health Association, Washington.

Baker, J.L., and J.M. Laflen. 1982. Effects of corn residue and fertilizer management on soluble nutrient runoff losses. Transactions of the American Society of Agricultural Engineers 25: 344348.

Cooke, J. G. and T. Dons. 1988. Sources and sinks of nutrients in a New Zealand hill pasture catchment. I. Stormflow generation. Hydrological Processes 2: 109-122.

Dils, R.M., and A.L. Heathwaite. 1996. Phosphorus fractionation in hillslope hydrological pathways contributing to agricultural runoff. pp: 229-251. In M.G. Anderson and S.M. Brooks (ed.) Advances in hillslope processes. John Wiley and Sons Ltd., Chichester.

Gardiner, M.J. 1986. Soil, site and climatic factors in slurry disposal. Irish Journal of Agricultural Research 25: 273-284.

Gentry, L.E., M.B. David, K.M. Smith-Starks, and D.A. Kovacic. 2000. Nitrogen fertilizer and herbicide transport from tile drained fields. Journal of Environmental Quality 29: 232-240.

Gisi, U., and J.J. Oertli. 1981. Oekologische Entwicklung in Brachland verglichen mit Kulturwiesen. Acta Ecologica 2: 79-86.

Hawkins, J.M.B., and D. Scholefield. 1996. Molybdate-reactive phosphorus losses in surface and drainage water from permanent grassland. Journal of Environmental Quality 25: 727-732.

Heathwaite, A.L. 1993. The impact of agriculture on dissolved nitrogen and phosphorus cycling in temperate ecosystems. Chemistry and Ecology 8: 217-231.

McColl, R.H.S. 1979. Factors affecting downslope movement of nutrients in hill pasture. Progress in Water Technology 11: 271-285.

McGarrigle, M.L., J.J. Bowman, K.J. Clabby, J. Lucey, P. Cunningham, M. MacCárthaigh, M. Keegan, B. Cantrell, M. Lehane, C. Clenaghan, and P.F. Toner. 2002. Water Quality in Ireland 1998-2000. Environmental Protection Agency, Wexford.

Nash, D., M. Hannah, D. Halliwell, and C. Murdoch. 2000. Factors affecting phosphorus export from a pasture-based grazing system. Journal of Environmental Quality 29: 1160-1166.

Pote, D.H., T.C. Daniel, D.J. Nichols, A.N. Sharpley, P.A. Moore, Jr., D.M. Miller and D.R. Edwards. 1999. Relationship between phosphorus levels in three Ultisols and phosphorus concentrations in runoff. Journal of Environmental Quality 28: 170-175.

Stamm, C., H. Flühler, R. Gächter, J. Leuenberger, and H. Wunderli. 1998. Preferential transport of phosphorus in drained grassland soils. Journal of Environmental Quality 27: 515-522.

Vollendweider, R.A. 1971. Scientific fundamentals of the eutrophication of lakes and flowing waters, with particular reference to nitrogen and phosphorus as factors in eutrophication. OECD, Paris. 